\title{
Efek Antifertilitas Ekstrak Air dari Biji Carica papaya terhadap Keteraturan Siklus Estrus Mencit (Mus musculus L.)
}

\section{Anti-Fertility Effects Of Carica papaya Water Seed Extract on Mice (Mus musculus) Oestrous Cycle}

\author{
Agung Janika Sitasiwi*, Siti Muflikhatun Mardiati \\ Departemen Biologi, Fakultas Sains dan Matematika, Universitas Diponegoro \\ Jl. Prof. Soedarto, SH, Tembalang, Semarang \\ *Email : agssiwi@yahoo.co.id
}

Diterima 4 Juli 2016 / Disetujui 18 Agustus 2016

\begin{abstract}
ABSTRAK
Penellitian ini bertujuan untuk mengevaluasi efek antifertilitas ekstrak air biji pepaya dalam mempengaruhi keteraturan siklus estrus mencit. Mencit strain Swiss Webster betina dara digunakan sebagai hewan uji. Hewan uji dibagi dalam 5 kelompok perlakuan, yaitu $\mathrm{K}(-)$, bahan perlakuan berupa akuades; $\mathrm{K}(+)$, bahan perlakuan sediaan pil kontrasepsi merk X dengan dosis ; P1, bahan perlakuan ekstrak air biji pepaya dengan dosis 1,4 mg/ekor/hari; P2, bahan perlakuan ekstrak air biji pepaya dengan dosis 3,5 mg/ekor/hari; P3, bahan perlakuan ekstrak air biji pepaya dengan dosis 1,4 mg/ekor/hari. Masing-masing kelompok perlakuan diulang 7 kali. Perlakuan diberikan selama 21 hari. Pengamatan siklus estrus dilakukan dengan membuat sediaan apus vagina dengan pewarnaan Giemsa, setiap 5 hari. Persentase keteraturan siklus estrus ditentukan dengan menghitung jumah hewan yang mengalami siklus estrus teratur dibandingkan jumlah seluruh hewan uji pada kelompok perlakuan yang sama. Efek penghambatan siklus estrus esktrak air dari biji pepaya ditunjukkan pada P2 dan P3 yang memiliki keteraturan siklus estrus 57.1 dan $42.8 \%$. Hasil penelitian ini membuktikan bahwa paparan esktrak air dari biji pepaya menunjukkan efek antifertilitas dengan mempengaruhi siklus estrus hewan uji.
\end{abstract}

Kata kunci: C. papaya, antifertilitas, siklus estrus

\begin{abstract}
ABTRACT
The aim of this experiment was to evaluate the effect of Carica papaya seeds water extract on mice oestrous cycle. Swiss Webster female mice (Mus musculus L.) were used as animal model. The animal model were divided into five treatment groups. $\mathrm{K}$ - group, control group were administered aquadest; $\mathrm{K}+$ group, positive control group were administered contraceptive pills; P1 to P3 were administered orally with C. papaya seeds extract water at doses of 1.4, 3.5, $7 \mathrm{mg} / \mathrm{animal} /$ day, respectively. Each treatment group were repeated 7 times. Treatment was given during 21 days. The oestrous cycle determined by vaginal smears that were taken every 5 days with Giemsa staining. The oestrous cycle percentage was calculated by comparing the sum of the animal model that had an irregular oestrous cycle to the sum of all animal models in the same group. The disturbances effect of Carica papaya seeds water extract on oestrous cycle were showed on P2 and P3 group which had $57.1 \%$ and $42.8 \%$ respectivetly. This experiment showed that Carica papaya L. seeds water extract showed an antifertility effect by disturbing estrous cycle of mice.
\end{abstract}

Keywords: Carica papaya, antifertility, oestrous cycle 


\section{PENDAHULUAN}

Antifertilitas merupakan istilah yang digunakan untuk senyawa atau bahan yang dapat mengganggu sistem reproduksi (Dabhadkhar et al., 2015), dengan cara menghambat proses praovulasi dan atau pra-implantasi embrio (Brewis and Combie, 1999). Joshi et al. (2011) menyatakan bahwa paparan senyawa antifertilitas dapat menyebabkan destruksi zigot, pencegahan ovulasi, fertilisasi atau implantasi.

Salah satu sumber senyawa antifertilitas adalah senyawa aktif yang terkandung dalam tanaman. Joshi et al. (2011) menyatakan bahwa senyawa aktif dalam tumbuhan secara alami memiliki sifat estrogenik yang ringan serta sifat anti-estrogenik yang cukup kuat sehingga berpeluang digunakan sebagai bahan pengatur fertilitas. Bala et al. (2014) menyatakan bahwa ekstrak tanaman obat mengandung senyawa aktif yang berperan sebagai antifertilitas dengan efek antiovulasi dan atau antiimplantasi sehingga dapat digunakan sebagai bahan kontrasepsi herbal.

Studi fitokimia telah membuktikan $C$. papaya mengandung alkaloid, carpain, nikotin, flavonol, tanin, dan terpene serta enzim seperti papain dan chymopapain (Adeneye and Olagunju, 2009). Naggayi et al. (2015) menyatakan bahwa senyawa yang terkandung dalam ekstrak air biji pepaya adalah saponin, tanin, flavonol, glikosida, terpeoid, alkaloid, pereduksi gula, asam amino, lemak, protein, fenol, vitamin, sterol dan triterpene. Senyawa golongan saponin, tanin, flavonoid, terpenoid, alkaloid, sterol serta triterpene dapat menekan tingkat fertilitas dengan cara mengganggufungsi ovarium, uterus atau vagina (Setyowati dkk., 2015).

Raji et al. (2005) menyatakan bahwa semua bagian buah C. papaya (epicarpium, endocarpium serta biji) memiliki kemampuan antifertilitas. Efek antifertilitas biji pepaya diduga bekerja dengan cara mempengaruhi sekresi hormon reproduksi (Raji et al., 2005; Udoh et al., 2005). Khrisna (2008) menyatakan bahawa esktrak biji pepaya bersfat anti-zigotik, anti-implantation, abortifacient awal atau aktivitas antifertilitas.
Penelitian Siburian dkk. (2008) membuktikan sifat antifertilitas biji pepaya mempengaruhi reproduksi tikus Wistar. Walansendow et al. (2016) menyatakan bahwa pemberian ekstrak biji pepaya pada tikus Wistar menurunkan kualitas spermatozoa sehingga menurunkan rasio kebuntingan.

Salah satu proses reproduksi yang dapat diamati dengan mudah akibat paparan senyawa antifertilitas pada hewan betina adalah keteraturan siklus estrus hewan uji. Ganong (2003) menyatakan bahwa siklus estrus merupakan ekspresi perubahan fluktuasi hormon reproduksi dalam tubuh hewan. Schatten dan Constantinenchu (2007) menyatakan bahwa siklus estrus merupakan suatu fase reproduksi pada hewan betina non primata yang terjadi secara berulang, ditandai dengan perubahan fisiologi dan tingkah laku. Siklus estrus pada rodensia berlangsung 4 sampai 5 hari, terdiri dari 4 fase, yaitu proestrus, estrus, metestrus dan diestrus. Penentuan fase penyusun siklus estrus dapat dilakukan dengan membuat apus vagina/vaginal smears/vaginal swap secara berkal (Bertholin and Murph, 2014).

Kokote et al. (2008) menyatakan bahwa efek paparan senyawa antifertilitas dapat dievaluasi pada proses reproduksi, yaitu dalam proses pembentukan gamet, regulasi sintesis atau sekresi hormon reproduksi pada organ reproduksi, proses pertemuan gamet jantan dan betina (fertilisasi) serta perkembangan awal individu baru. Pengujian senyawa antifertilitas dapat dilakukan dengan menggunakan beberapa hewan coba, diantaranya mencit (Mus musculus L.). Bertholin and Murph (2014) menyatakan bahwa mencit (M. musculus L.) memiliki laju reproduksi yang cukup tinggi serta mudah dalam pemeliharaan sehingga tepat digunakan sebagai hewan coba dalam penelitian reproduksi.

Berlatar belakang masalah di atas, dilakukan penelitian untuk mengevaluasi paparan kronis senyawa antifertilitas dalam ekstrak air biji pepaya dalam mempengaruhi keteraturan siklus estrus mencit. Hasil penelitian diharapkan dapat digunakan sebagai bahan rujukan dalam 
penggunaan esktrak biji pepaya sebagai bahan antifertilitas untuk meregulasi reproduksi mamalia.

\section{METODE PENELITIAN}

Penelitian ini dilakukan dengan Rancangan Acak Lengkap, dengan 5 perlakuan dan 7 ulangan. Paparan hewan uji diberikan selama 21 hari. Kelompok perlakuan terdiri dari Kontrol Negatif (K-) berupa perlakuan dengan pelarut bahan uji (air), Kontrol Positif $(\mathrm{K}+$ ) berupa

perlakuan dengan sediaan kontrasepsi sintetis (pil kontrasepsi merk "X"), P1 adalah kelompok perlakuan dengan dosis bahan uji 1.4 $\mathrm{mg} / \mathrm{ekor} /$ hari, P2 yaitu kelompok perlakuan dengan dosis bahan uji 3,5 mg/ekor/hari, dan P3 yaitu kelompok perlakuan dengan dosis bahan uji konsentrasi $7 \mathrm{mg} / \mathrm{KgBB} /$ hari.

Hewan uji yang digunakan adalah mencit galur Swiss Webster, jantan dan betina dara berumur 2.5-3 bulan dengan rataan bobot badan 25-30 gram, tanpa cacat anatomis, diperoleh dari Laboratorium Pemeliharaan Hewan Jurusan Biologi FMIPA Universitas Negeri Semarang. Hewan uji dipelihara dalam dipelihara dengan kepadatan 3 ekor hewan per kandang, setelah diaklimasikan dalam kondisi laboratorium selama 1 minggu.

Pemberian pakan dan minum dilakukan secara ad libitum. Pakan yang diberikan adalah pakan standard dengan kode 594. Pemeliharaan dilakukan sesuai metode Sitasiwi dan Djaelani (2011). Mencit betina dewasa yang terpilih untuk digunakan adalah yang memiliki siklus estrus tetap selama minimal 3 siklus (Nivsarkar et al., 2001; Hayashi et al., 2009; Sitasiwi dan Djaelani, 2011).

\section{Persiapan Bahan Uji}

Bahan uji yang diberikan adalah serbuk biji pepaya. Serbuk biji pepaya diperoleh dari beberapa pohon pepaya dengan jenis yang sama, ditanam di daerah Gedawang, Banyumanik Semarang. Ekstrak biji C. papaya yang diperoleh dengan cara mencuci biji pepaya dengan air mengalir, kemudian dikeringkan menggunakan oven pada suhu $40{ }^{\circ} \mathrm{C}$ selama 10 hari. Biji $C$. papaya yang telah kering, dibuat tepung dengan cara dihancurkan dengan blender, kemudian diayak. Tepung biji $C$. papaya disiapakan sebagai bahan uji sesuai dengan dosis yang diberikan, dilarutkan dengan cara melarutkan tepung biji pepaya menggunakan air mendidih. Pemberian bahan uji dilakukan saat air seduhan biji pepaya telah mencapai suhu ruang.

Kelompok perlakuan kontrol positif diberi sediaan kontrasepsi sintetis berupa pil kontrasepsi merk "X" (mengandung ethinylestradiol $0.03 \mathrm{mg}$ dan levonorgestrel $0.15 \mathrm{mg}$ ), dengan dosis harian sesuai dosis harian pada manusia. Pil KB dihancurkan menggunakan grinder dan dilarutkan menggunakan air hangat.

\section{Perlakuan dan Pengambilan Data}

Pemberian bahan perlakuan diberikan secara oral menggunakan jarum "gavage" dengan volume $0,5 \mathrm{~mL} /$ hewan uji, pada sore hari (15.0016.00 WIB), selama 21 hari berturut-turut. Pengamatan siklus estrus dilakukan dengan cara apus vagina dengan pewarnaan Giemsa 5\%, sesuai metode Nivsarkar et al. (2001), Hayashi et al. (2009), Sitasiwi dan Djaelani (2011). Keteraturan siklus estrus hewan uji ditentukan dengan mengamati fase penyusun siklus estrus setiap 5 hari sekali, selama perlakuan berlangsung. Hewan uji yang menunjukkan minimal tiga fase penyusun siklus estrus yang sama secara berturut-turut selama lima kali pengamatan, maka hewan uji tersebut dianggap mengalami siklus estrus yang teratur. Siklus estrus hewan uji dikatakan tidak teratur apabila hewan uji menunjukkan fase estrus yang berbeda selama lima kali pengamatan. Penentuan persentase keteraturan siklus estrus hewan uji selama paparan dilakukan dengan menghitung jumlah hewan uji yang mengalami siklus estrus teratur dibandingkan total jumlah hewan uji pada kelompok perlakuan yang sama.

\section{HASIL DAN PEMBAHASAN}

Penelitian mengenai senyawa antifertilitas ekstrak C. papaya sampai saat ini masih terkonsentrasi pada hewan jantan (Raji et al., 
2005). Penelitian ini dilakukan dengan tujuan mengevaluasi efek paparan senyawa antifertilitas dalam ekstrak air biji pepaya terhadap keteraturan siklus estrus. Penentuan siklus estrus pada penelitian ini dilakukan dengan menggunakan apus vagina/vaginal smear, sesuai metode Hayashi et al. (2009) disajikan pada Gambar 1. Hasil apus vagina dengan sel-sel yang memiliki morfologi yang berbeda, yaitu sel yang berinti (A) dan sel yang telah mengalami kornifikasi berbentuk lempeng tanpa inti (B).

Siklus estrus merupakan siklus yang terutama diregulasi oleh hormon estrogen. Hormon estrogen mempengaruhi struktur histologi lapisan epitel penyusun dinding vagina, sehingga sel epitel vagina mengalami perubahan selama siklus estrus (Schatten dan Constantinenchu, 2007). Hayashi et al. (2009) menyatakan bahwa hasil apus vagina pada fase proestrus sel epitel masih berbentuk bulat. Fase estrus memperlihatkan sel-sel epitel yang sudah mengalami kornifikasi, tanpa inti dan dengan pewarnaan Giemsa berwarna biru pucat. Hewan coba yang berada pada fase metestrus ditandai dengan epitel kornifikasi dengan jumlah yang sedikit dengan jumlah leukosit yang cukup tinggi. Hasil apus vagina hewan coba yang berada pada fase diestrus menunjukkan sel-sel yang berbentuk kolumnar dengan inti sel yang jelas.

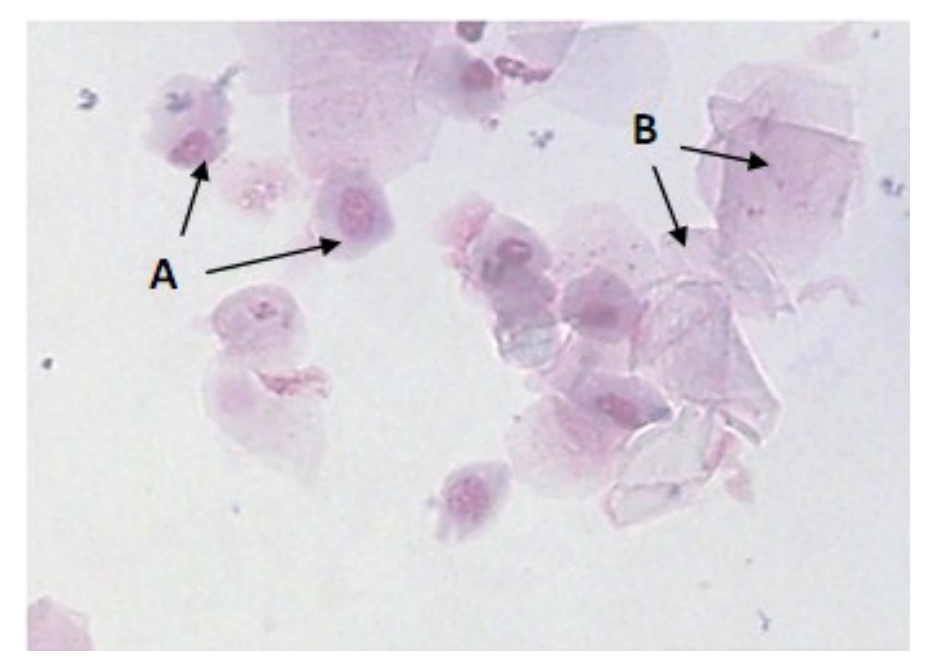

Gambar 1. Hasil Apus Vagina Mencit

Keterangan :

A. Epitel berinti

B. Epitel kornifikasi

Siklus estrus pada hewan dipengaruhi oleh faktor intrinsik dan esktrinsik. Faktor intrinsik utama yang mempengaruhi siklus estrus adalah umur dan genetik (Schatten and Constantinescu, 2007). Faktor ekstrinsik diantaranya adalah fotoperiodisme, suhu dan suplai makanan. Penelitian ini dilakukan dengan menggunakan hewan uji berupa mencit (M. musculus L.) strain Swiss Webster dengan umur yang seragam yaitu 2,5 bulan. Hal tersebut menunjukkan bahwa faktor intrinsik, berupa umur dan genetik, tidak mempengaruhi hasil penelitian ini. Pemeliharan hewan uji dalam penelitian ini dilakukan dalam kondisi laboratorium yang terkontrol, sehingga dapat dipastikan hasil ini disebabkan oleh perlakuan bahan uji yang diberikan, yaitu esktrak air dari biji pepaya.

Hasil penghitungan persentase hewan uji yang mengalami siklus estrus selama penelitian disajikan pada Gambar 2. Gambar 2 menunjukkan bahwa paparan senyawa antifertilitas dalam biji pepaya terbukti mempengaruhi keteraturan siklus 
estrus. Hal tersebut ditunjukkan dengan persentase hewan uji yang mengalami gangguan keteraturan siklus estrus meningkat seiring dengan peningkatan dosis paparan senyawa antifertilitas dalam bahan uji. Persentase hewan uji yang diberi paparan senyawa antifertilitas dengan dosis P1 menunjukkan keteraturan siklus estrus yang relatif sama dengan $\mathrm{K}$ - dan kelompok kontrol positif $\mathrm{K}+$, yaitu berkisar $83 \%$. Hal tersebut dapat diartikan hewan uji yang memiliki siklus estrus tidak teratur berkisar $15-17 \%$ dari keseluruhan hewan uji.

Hewan uji pada kelompok kontrol negatif (K-) hanya mendapatkan paparan akuades sehingga jumlah hewan uji yang mengalami siklus estrus teratur menunjukkan rerata 83,3\%. Bertholin dan Murph (2014) menyatakan bahwa siklus estrus mencit dalam populasi yang dipelihara dalam kondisi laboratorium menunjukkan keteraturan yang cukup tinggi, yaitu $>80 \%$. Hasil penelitian pada kelompok $\mathrm{K}+$ dan $\mathrm{P} 1$ juga menunjukkan rerata keteraturan siklus estrus diatas $80 \%$. Hal tersebut menggambarkan bahwa perlakuan dengan akuades, pil kontrasepsi serta ekstrak air biji pepaya dengan dosis 1,4 $\mathrm{mg} / \mathrm{ekor} / \mathrm{hari}$ memiliki potensi yang sama dalam mempengaruhi siklus estrus hewan uji.

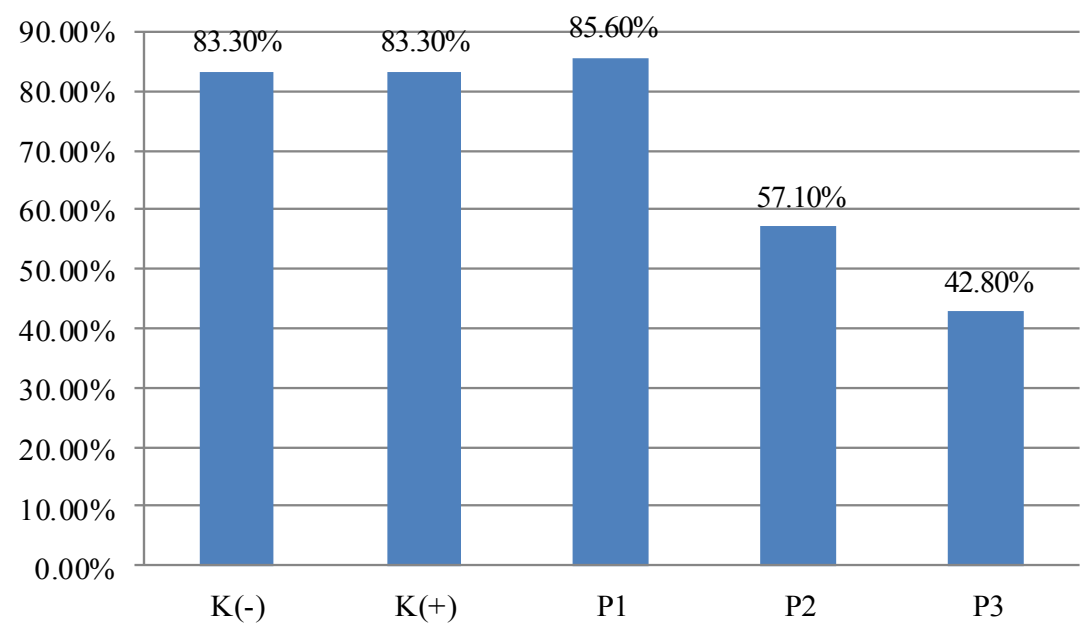

Gambar 2. Efek paparan esktrak air biji pepaya (C. papaya) terhadap keteraturan siklus estrus dan frekuensi kebuntingan mencit (M. Musculus)

Pil konrasepsi yang diberikan dalam hewan uji kelompok $\mathrm{K}+$ mengandung ethynil estradiol dan levonorgestrel. Ganong (2003) menyatakan bahwa ethynil estradiol merupakan estrogen sintetik yang memiliki potensi yang sama dengan estrogen. Hormon ini relatif aktif jika diberikan per oral karena resistan terhadap metabolisme hepatik. Aktivitas alami hormon ini relatif rendah dalam tubuh ketika diberikan lewat jalur digesti karena vena porta intestinum akan membawa ke hepar, dimana hormon tersebut diinaktivasi sebelum masuk sistem sirkulasi. Efek selektif estrogen sintetis ditentukan oleh selective estrogen receptor modification (SERMs) dan berkaitan dengan perbedaan cara kompleks reseptor-ligan untuk berikatan pada DNA. Levonorgestrel merupakan progesteron sintetik, memiliki efektivitas yang tinggi dan dapat diteloransi dengan baik oleh tubuh. Hewan uji yang menunjukkan hasil keteraturan siklus estrus yang relatif sama dengan kelompok kontrol negatif (K-) dan P1 diduga disebabkan oleh paparan dengan dosis tersebut belum mempengaruhi regulasi sistem hormon reproduksi dalam tubuh.

Hasil penelitian juga menunjukkan bahwa semakin tinggi dosis bahan uji yang diberikan semakin menurunkan jumlah hewan yang mengalami siklus estrus teratur. Hewan uji pada 
kelompok kontrol memiliki siklus estrus yang lebih tinggi dibandingkan dengan hewan uji pada kelompok perlakuan dengan paparan bahan yang mengandung senyawa antifertilitas. Hewan uji pada kelompok perlakuan P1 menunjukkan keteraturan siklus estrus yang relatif sama dengan $\mathrm{K}$ - dan $\mathrm{K}+$. Hewan uji kelompok perlakuan P2 dan P3 menunjukkan keteraturan siklus estrus yang rendah, yaitu 57,1 \% (P2) dan 42,8\% (P3).

Mekanisme gangguan siklus estrus yang terjadi karena paparan esktrak air biji pepaya dapat terjadi melalui beberapa cara. Cara pertama adalah gangguan pada sekresi hormon reproduksi. Udoh (2005) menyatakan bahwa bahan antifertilitas triterpenoid dan saponin bekerja pada aksis hipotalamus-hipofisis-gonad, sehingga mempengaruhi sekresi hormone gonadotropin. . Francis et al. (2002) menyatakan bahwa saponin secara langsung menghambat kerja gen yang berperan dalamsteroidogenesis dan menekan perkembangan sel dalam ovarium yang diatur oleh FSH. Raji et al. (2005) menyatakan ekstrak air biji pepaya memiliki kemampuan antifertilitas dengan cara mempengaruhi sekresi hormon estrogen sehingga menyebabkan gangguan siklus estrus pada tikus Wistar.

Mekanisme gangguan siklus estrus yang kedua adalah sifat sitotoksik dan sitostatik senyawa yang terdapat dalam esktrak air biji pepaya. Setyowati dkk. (2015) menyatakan bahwa tanin merupakan senyawa yang bersifat sitotoksik. Efek sitotoksik dapat terjadi pada ovarium sehingga mempengaruhi pembelahan sel dalam proses oogenesis atau terjadi pada uterus sehingga proses perkembangan awal embrio terganggu.

\section{SIMPULAN}

Hasil penelitian membuktikan bahwa senyawa antiferilitas dalam esktrak air biji pepaya (C. papaya L.) mampu mempengaruhi siklus estrus Mus musculus L. sehingga dapat digunakan sebagai salah satu bahan untuk meregulasi reproduksi mamalia.

\section{UCAPAN TERIMA KASIH}

Penulis mengucapkan terima kasih kepada Dekan Fakultas Sains dan Matematika Universitas Diponegoro yang telah memberi biaya pelaksanaan penelitian melalui dana DIPA Fakultas Sain dan Matematika Universitas Diponegoro sesuai dengan Perjanjian Tugas Pelaksanaan Penelitian Para Dosen di Departemen Biologi Fakultas Sain dan Matematika Universitas Diponegoro No.1110Ep/UN.7.3.8/PG/2016 Tanggal 1 Maret 2016.

\section{DAFTAR PUSTAKA}

Adeneye, A.A. and J.A. Olagunju, 2009. Preliminary Hypoglycemic and Hypolypidemic Activities of the Aqueous Seeds Extract of Carica papaya Linn, in Wistar Rat. Biology and Medicine 1(1): 110.

Bala, K., M. Arya, D.P. Katare, 2014. Herbal Contraceptive: An Overview. World Journal of Pharmacy and Pharmaceutical Science. 3(8): 1309-1326.

Bertholin and Murph, 2014. Reproductive Tract Changes during the Mouse Estrous Cycle. Academic Press, http://bit.ly/lv3LeqB.Thu, 07/03/2014 - 4:24pm.

Brewis, A.A., and R.C. Combie, 1999. Antifertility Plant of The Pacific. CSIRO Publisher. Australia.

Dabhadkhar, D.K., V.G. Thakare, V.S. Zade, A.P. Charjan, M.M. Dhore, S.M. Deosthale, 2015. Review on Some Ethnobotanical Plants Having Antifertility Activity in Female Albino Rats. Int. Res. J. of Science and Engineering. 3(2): 43-46.

Francis, G., Z. Kerem, H.P.S. Makkar and K. Becker, 2002. The biological action of saponins in anymal system: Review. British Journal of Nutrition. 88: 587-605.

Ganong, W.F., 2003. Review of Medical Physiology. International Ed. Boston. Pp. 443- 446. 
Hardy, C.M., G. Clysdale, dan K.J. Mobbs., 2004. Development of the Mouse-Specific Contaceptive Vaccines: Infertility in Mice Imunized with Peptide and Polyepitope Antigens. Reprod. 128: 395-407.

Hayashi, K., D.W. Erikson, S.A. Tilford, B.M. Bany, J.A. Maclean,E.B. Rucker, G.A. Johnson, and T.E. Spencer, 2009. Wnt Genes in the Mouse Uterus: Potential Regulation of Implantation. Biol.Reprod. 88:989-1000.

Joshi, M., K. Gaonkar, S. Mangoankar, and S. Satarkar, 2011. Pharmacological Investigation of Areca catechu Extracts for Evaluation of Learning, Memory, and Behaviour in rats. International Current Pharmaceutical Journal. 1(6): 128-132.

Khrisna, K.L., M. Paridhavi, and J.A. Patel, 2008. Review on Nutritional, Medicinal, and Pharmacological Properties of Papaya (Carica papaya L.). Natural Product Radiance. 7(4): 364-73.

Kokote, C.K., A.P. Purohit, S.B. Gokhale, 2008. Pharmacognosy. $\quad 42^{\text {th }} \quad$ Edition.Nirali Prakashan. Pp. 37-39.

Naggayi, Madinah, M. Nozmo, I. Ezekiel, 2015. The Protective Effects of Aqueous Extract on Carica papaya seeds in Paracetamol Induced Nephrotoxicity in Male Wistar Rats. African Health Sciences. Vol. 15 Issue 2.

Nivsarkar, M., A. Sethi, C. Bapu, M. Patel, and H. Padh, 2001. Involvement of endometrial; membrane sulphydryl groups in blastocyst implantation: sulphydryl groups as a potential target for contraceptive research. Contraception. 64:255-259

Raji, Y., A.O. Morakinyo, A.K. Oloyo, O.S.Akinsomisoye, Olufadekemi, T. Kunle-Alabi, P.R.C. Esegbue-Peters, F.O Awobajo, 2005. Impact of the Chloroform Extract of Carica papaya Seed on Oestrous cycle and Fertility in Female Albino Rats.J.Med. Sci. 5(4): 337-343.
Schatten, H. and G.M. Constantinescu, 2007. Comparative Reproductive Biology. First Edition. Blackwell Publishing. Iowa.

Setyowati, E. A. W., A.D. R. Sri, Ashadi, M. Bakti, H. Arif, 2015. Aktivitas antifertilitas kontrasepsi kulit durian (Durio zibethinus Murr.) varietas Petruk. PS Pendidikan Kimia. Jurusan PMIPA FKIP UNS. Surakarta.

Siburian, J., J.Marlina, A. Johari, 2008. Pengaruh Ekstrak Bii Pepaya (Carica papaya L.) pada Tahap Prakopulasi Terhadap Fungsi Reproduksi Mencit (Mus musculus L.)Swiss Webster Betina. Laporan Penelitian.PS Pendidikan Biologi Jurusan Pendidikan MPA FKIP Universitas Jambi.

Sitasiwi, A.J. dan M.A. Djaelani, 2011. Studi awal upaya eksplorasi agensia imunokontrasepsi untuk regulasi fertilitas hewan liar: Profil protein selama proses implantasi embrio mencit (Mus musculus L.) BALB/c. BIOMA.13(1): $39-45$.

Udoh, P., I. Essien, F. Udoh, 2005. Effects of Carica papaya (paw paw) seeds extract on the morphology of pituitary-gonadal axis of male Wistar rats. Phytotherapy Research. 19(12):1065-1068.

Walansendow, R., M.R. Janette, dan T. Lydia, 2016. Pengaruh Pemberian Ekstrak Biji Pepaya (Carica papaya L.) terhadap Kualitas Sperma Tikus Wistar (Rattus norvegicus). Jurnal e-Biomedik (eBm). 4(1): $1-4$. 